\title{
Anterior Meningeal Artery
}

National Cancer Institute

\section{Source}

National Cancer Institute. Anterior Meningeal Artery. NCI Thesaurus. Code C32099.

An anterior ethmoidal artery branch that supplies the meningeal tissues in the anterior fossa of the cranium. 